\title{
Use of highway culverts by the water opossum (Chironectes minimus) in southeastern Brazil
}

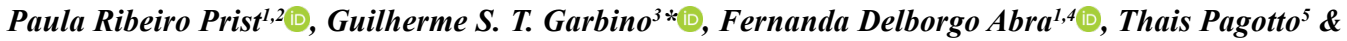 \\ Osnir Ormon Giacon \\ ${ }^{1}$ ViafaUNA, São Paulo, SP, Brasil. \\ ${ }^{2}$ Universidade de São Paulo, Instituto de Biociências, São Paulo, SP, Brasil. \\ ${ }^{3}$ Universidade Federal de Minas Gerais, Instituto de Ciências Biológicas, Programa de Pós-Graduação em \\ Zoologia, Campus Pampulha, Belo Horizonte, MG, Brasil. \\ ${ }^{4}$ Center for Conservation Education and Sustainability, Smithsonian Conservation Biology Institute, National \\ Zoological Park, Washington, DC, United States. \\ ${ }^{5}$ Concessionária Auto Raposo Tavares, Bauru, SP, Brasil. \\ *Corresponding author: Guilherme S. T. Garbino, e-mail: gstgarbino@hotmail.com
}

PRIST, P.R., GARBINO, G.S.T., ABRA, F.D., PAGOTTO, T., GIACON, O.O. Use of highway culverts by the water opossum (Chironectes minimus) in southeastern Brazil. Biota Neotropica 20(4): e20201058. https://doi.org/10.1590/1676-0611-BN-2020-1058

\begin{abstract}
The water opossum (Chironectes minimus) is a semi-aquatic mammal that is infrequently sampled in Atlantic rainforest areas in Brazil. Here we report on new records of $C$. minimus in the state of São Paulo, southeastern Brazil, and comment on its behavior and ecology. We placed nine camera traps in culverts and cattle boxes under a highway, between 2017 and 2019. From a total of 6,750 camera-trap-days, we obtained 16 records of $C$. minimus ( 0.24 records/100 camera-trap-days) in two cameras placed in culverts over streams. Most of the records were made between May and August, in the dry season and in the first six hours after sunset. The new records are from a highly degraded area with some riparian forests. The records lie approximately $30 \mathrm{~km}$ away from the nearest protected area where the species is known to occur. We suggest that $C$. minimus has some tolerance to degraded habitats, as long as the water bodies and riparian forests are minimally preserved. The new records presented here also fill a distribution gap in western São Paulo state.
\end{abstract}

Keywords: Atlantic rainforest; camera traps; Didelphidae; wildlife passages.

\section{Uso de drenagens fluviais sob rodovias pela cuíca d'agua (Chironectes minimus) no sudeste do Brasil}

Resumo: A cuíca d'agua (Chironectes minimus) é um mamífero semiaquático pouco amostrado em áreas de Mata Atlântica do Brasil. Neste estudo apresentamos novos registros de C. minimus no estado de São Paulo, sudeste do Brasil, e comentamos sobre seu comportamento e ecologia. Nós instalamos nove armadilhas fotográficas em drenagens fluviais e passagens de gado sob uma rodovia, entre 2017 e 2019 . De um total de 6.750 armadilhasfotográficas-dia, obtivemos 16 registros de C. minimus ( 0,24 registros/100 armadilhas-fotográficas-dia) em duas armadilhas fotográficas instaladas em drenagens fluviais. A maioria dos registros foram feitos entre maio e agosto, na estação seca, e nas seis primeiras horas da noite. Os novos registros são de uma área altamente degradada que possui algumas matas ciliares. Os registros estão a aproximadamente $30 \mathrm{~km}$ da área protegida mais próxima onde a espécie já foi registrada. Nós sugerimos que $C$. minimus possui certa tolerância a hábitats degradados, contanto que os corpos d'agua e as matas ciliares estejam minimamente preservados. Os novos registros aqui apresentados também preenchem uma lacuna amostral no oeste de São Paulo.

Palavras-chave: armadilhas fotográficas; Didelphidae; Mata Atlântica; passagens de fauna. 


\section{Introduction}

Our understanding of the ecology (Galliez et al. 2009, Fernandez et al. 2015) and distribution (Ardente et al. 2013, Brandão et al. 2015) of the water opossum (Chironectes minimus) has substantially improved in recent years. It is now assumed that $C$. minimus is continuously distributed from southern Mexico southwards to northern Argentina and southern Brazil (Stein \& Patton 2008, Astúa 2015). In Brazil, C. minimus occurs in every biome, except in the dry forests of the Caatinga (Melo \& Sponchiado 2012, Brandão et al. 2015). In the Atlantic Forest biome, most of the locality records are near the Atlantic coast (Stein \& Patton 2008, Melo \& Sponchiado 2012). In São Paulo state, southeastern Brazil, it is known from one historical (Pelzeln 1883) and five recent localities (Carvalho 1965, Nogueira et al. 2004, Prada 2004, Breviglieri \& Pedro 2010, Faria \& Pires 2010), in the Cerrado and Atlantic Forest biomes.

Most of the information on the ecology of C. minimus comes from studies carried out in Rio de Janeiro, southeastern Brazil, which have shed light on the home length, population density, use of shelters, and activity pattern of the species (Galliez et al. 2009, Leite et al. 2013, Fernandez et al. 2015, Leite et al. 2016). These and other reports show that $C$. minimus uses water bodies with sandy or stony substrates, fast-flowing water, and with well-preserved riparian forests (Palmeirim et al. 2014, Voss et al. 2001, Bressiani \& Graipel 2008). Although vehicle collisions are rare, a single roadkilled $C$. minimus was recorded among 444 roadkilled mammals in southern Brazil (Coelho et al. 2008), and in São Paulo state one $C$. minimus was found among 184 roadkilled mammals (Prada 2004).
A likely explanation for this relatively low number of roadkills is that, due to its association with water bodies, $C$. minimus rarely ventures across dry and usually elevated paved highways. Therefore, we expect that culverts under highways that have perennial water flow may increase the permeability of C. minimus in anthropized landscapes.

Recent papers have demonstrated that camera trapping methods can document a greater abundance of some mammals than what might be detected using conventional survey methods, such as transects and active search for footprints (Tobler et al. 2008, O'Brien et al. 2003, Gregory et al. 2015). In the case of $C$. minimus, specimen capture requires unconventional live traps set at specific places, such as narrow streams (Bressiani \& Graipel 2008). Given its elusiveness, camera trapping at strategic places might reveal more data on the ecology of the species (Oliveira-Santos et al. 2008). In road ecology studies, camera traps set at underpasses are often used in conjunction with tracks and roadkill monitoring (Grilo et al. 2008, González-Gallina et al. 2018). Therefore, such studies, besides assessing the highway impacts on mammals, might also be important to record poorly known species.

Here we report on a new locality of $C$. minimus for the state of São Paulo in southeastern Brazil, comment on its behavior as revealed in the camera trap videos and discuss on the importance of highway underpasses for the species persistence in anthropized areas.

\section{Material and Methods}

The study site is in western São Paulo state, southeastern Brazil, in the counties of Caiuá and Presidente Venceslau (Figure 1).

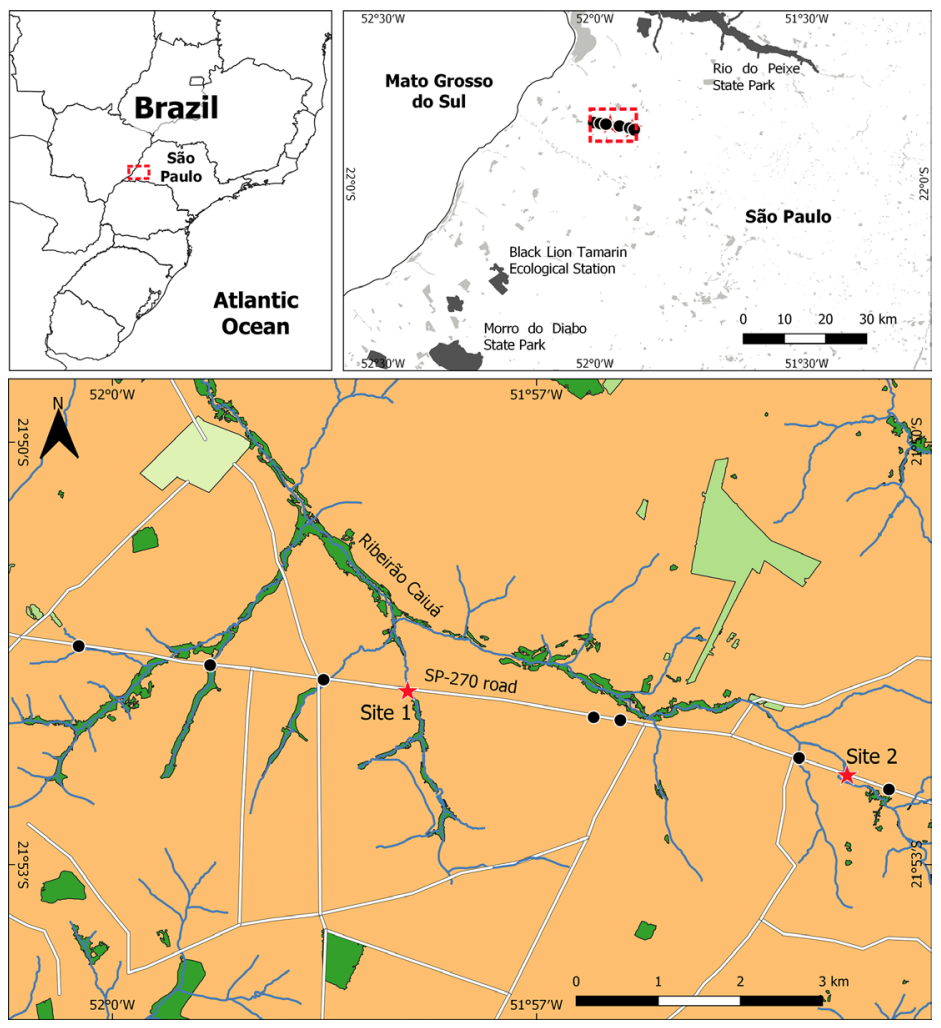

Figure 1. Study site, showing its location in Brazil and in the state of São Paulo (protected areas are in dark gray and unprotected forest fragments are in light gray). A total of nine camera-trap stations (black dots and red stars) were implemented, of which two (red stars) recorded C. minimus (Site $1-21^{\circ} 51^{\prime} 34.18$ "S; 51 $577^{\prime} 54.69^{\prime \prime} \mathrm{W}$ and Site $\left.2-21^{\circ} 52^{\prime} 10.05^{\prime \prime S} ; 51^{\circ} 54^{\prime} 48.16^{\prime \prime} \mathrm{W}\right)$. Camera traps were placed in underpasses over streams that fall in the Ribeirão Caiuá. In the larger map, orange represent anthropized areas, light green are eucalyptus plantations, dark green are native forest fragments, blue lines are streams, and white lines represent the road network. 
Originally, the area was predominantly composed of seasonal forests of the Atlantic rainforest, considered one of the world's biodiversity hotspot (Mittermeier et al. 2011). However, most of the original forest has been cut down and the remaining forest fragments are generally small $(<100 \mathrm{ha})$, restricted to riparian forests, and interspersed with sugarcane plantations and pasture (Uezu 2006, Ribeiro et al. 2009, Rezende 2014). The site is near four large protected areas $(>6,000$ ha each), to the north there are the Rio do Peixe State Park (ca. $33 \mathrm{~km}$ to the northeast) and the Aguapeí State Park (ca. $80 \mathrm{~km}$ to the northeast) (Faria \& Pires 2010). Approximately $47 \mathrm{~km}$ to the southwest is the Black Lion Tamarin Ecological Station (6,600 ha; Valladares Padua 2007), and further south (ca. $70 \mathrm{~km}$ ) is the Morro do Diabo State Park (33,000 ha), the largest fragment of seasonal forest in São Paulo state (Faria \& Pires 2006, Rezende 2014).

This study is part of a faunal monitoring project aimed at investigating the impact of highways in wildlife. In order to verify the use of small streams by wildlife, we monitored nine underpasses, including cattle boxes and culverts, along 10.7 kilometers of the SP-270 state highway (Figure 1, Table S1). Out of the nine monitored structures, $C$. minimus was recorded in two culverts, hereafter Site 1 (21 ${ }^{\circ} 51^{\prime} 34.18^{\prime \prime}$;

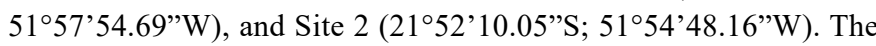
underpasses in Sites 1 and 2 were circular structures with width and height of approximately 2 meters. Following the rivers, the two sites with $C$. minimus records are $6.7 \mathrm{~km}$ apart and are both crossed by streams which form the Ribeirão Caiuá (main Caiuá river), a small stream that falls in the large Rio Paraná, approximately $19 \mathrm{~km}$ to the northwest. The two sampled streams have flowing water, sandy substrate, and a depth of water varying from approximately $0.2 \mathrm{~m}$ to $1 \mathrm{~m}$ along different seasons.
We placed nine Bushnell ${ }^{\mathrm{TM}}$ Aggressor No-Glow 20 MegaPixel camera traps in the middle of the passage structures aiming to detect wildlife crossing under the road. All cameras were in the field full time on and once per month the memory cards and batteries were replaced. Survey period was from November 2017 to November 2019. The highway was monitored for roadkilled animals during the same period.

All novel data on Chironectes minimus presented here were gathered from camera-traps. Records were considered as independent if the time between consecutive videos was more than 1 hour apart, following Tobler et al. (2008). To evaluate the activity period of $C$. minimus, data from the whole sampling period were pooled by hours after sunset and divided in four different periods of the night, following Galliez et al. (2009).

\section{Results}

There were 16 independent camera trapping records (19 movies) of Chironectes minimus over 6,750 camera-trap-days (750 in each of the nine stations), for a rate of 0.24 records/ 100 camera-trap-days (Table 1). Other animals observed in the videos that captured $C$. minimus were capybaras (Hydrochoerus hydrochaeris), and unidentified bats and frogs, but they did not interact with the water opossum. The records of C. minimus at Sites 1 and 2 occurred between 19:00 and 4:00 hours, with 10 out of $16(62 \%)$ made in the first six hours after sunset (Figure 2A). Most of the records $(81 \% ; 13$ of 16$)$ were made in the dry season (INMET 2019), between May and August (Figure 2B). No intraspecific interactions were observed, as only a single animal was present in every video. In the highway monitoring, no roadkilled C. minimus were recorded. Behaviors recorded include walking on dry substrate $(\mathrm{N}=14)$, walking on shallow water $(\mathrm{N}=9)$, swimming $(\mathrm{N}=4)$, entering water from dry substrate $(\mathrm{N}=5)$, and eating $(\mathrm{N}=1)$ (Figure 3; Table 1).

Table 1. Date, time, and observed behavior of the Chironectes minimus individuals filmed at Ribeirão Caiuá, São Paulo, Brazil. EAT = eating; ENT = entering water form dry substrate; SHA = walking on shallow water; SWI = swimming; WAL = walking on dry substrate.

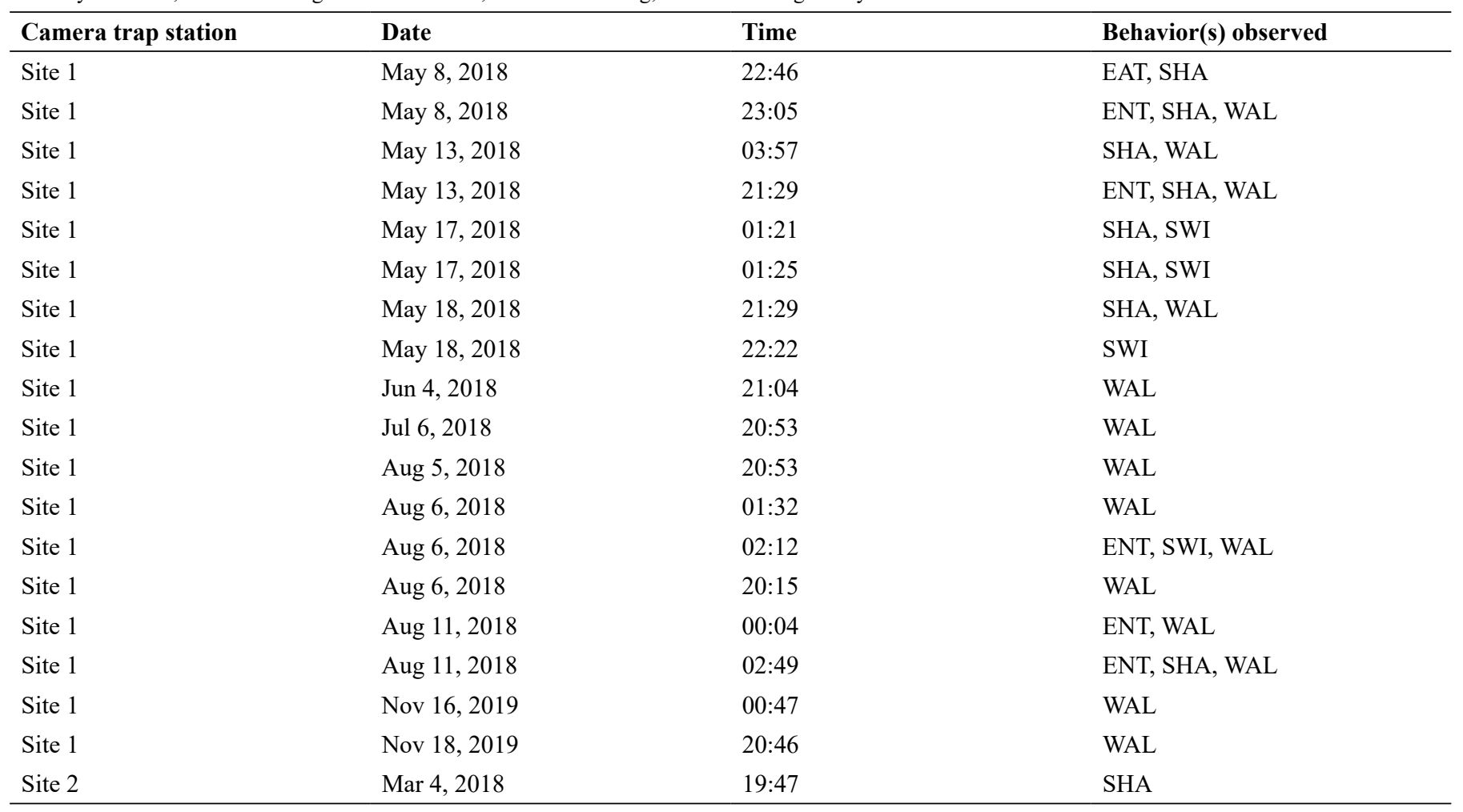



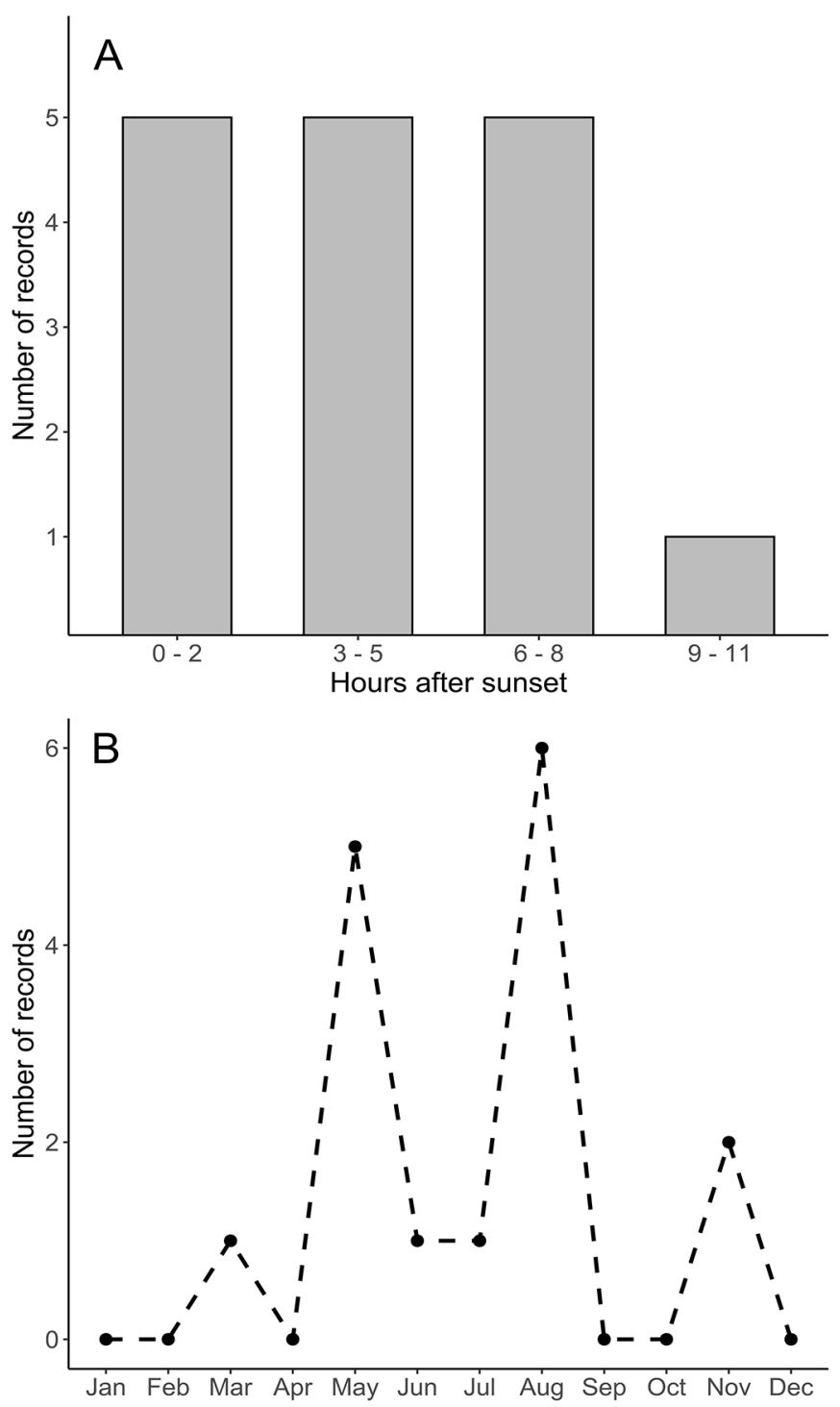

Figure 2. A) Activity pattern of Chironectes minimus in the Ribeirão Caiuá, São Paulo, Brazil. Number of records are based on camera trapping between November 2017 and November 2019; B) Monthly camera trap records of Chironectes minimus in Ribeirão Caiuá, São Paulo, Brazil, obtained between November 2017 and November 2019.

\section{Discussion}

Activity period inferred from the camera trap records agree with Galliez et al. (2009) and Leite et al. (2013), who recorded most of the activities of Chironectes minimus in the first half of the night. Leite et al. (2013) also observed a difference in seasonal activity, with males more active than females during the dry season. Here, records were more frequent in the dry season, but we could not determine the sex of the filmed individuals. Considering that the home length of $C$. minimus may vary between 0.8 and $9.6 \mathrm{~km}$ but few individuals have home lengths larger than $6.7 \mathrm{~km}$ (Fernandez et al. 2015, Leite et al. 2016), it is likely that the records reported herein represent at least two individuals.

The closest previous records of $C$. minimus are from relatively wellprotected areas in Rio Pardo (state of Mato Grosso do Sul), approximately $37 \mathrm{~km}$ to the west (Melo \& Sponchiado 2012), and Rio do Peixe State Park (São Paulo state), approximately $30 \mathrm{~km}$ to the north (Faria \& Pires 2010).
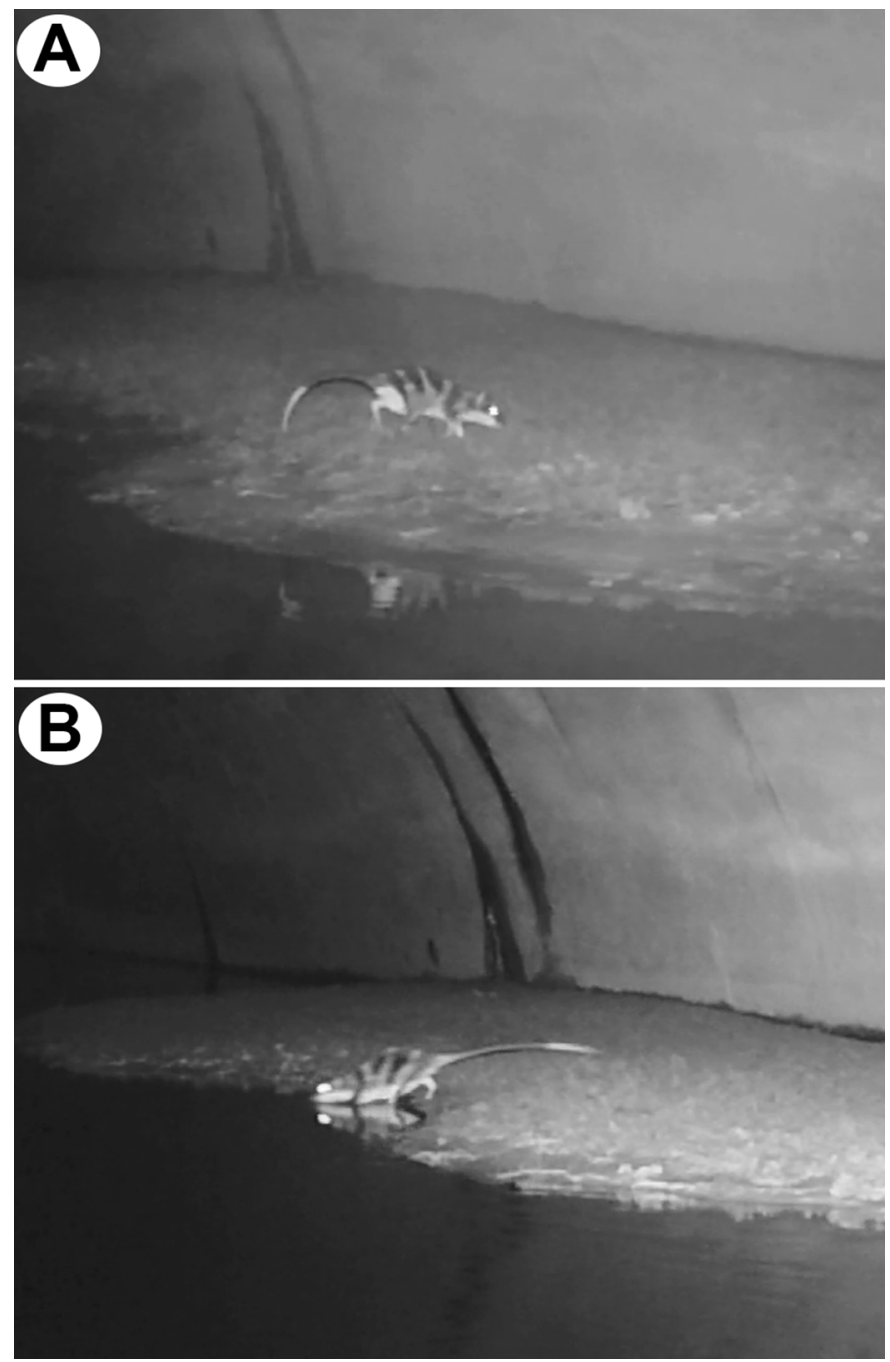

Figure 3. Behaviors recorded for Chironectes minimus: walking on dry substrate (A) and entering water (B).

However, the geographical coordinates given for the Rio Pardo locality (21 ${ }^{\circ} 46^{\prime}$ 'S, 52 ${ }^{\circ} 09^{\prime} \mathrm{W}$; Stein and Patton, 2008) refer to the mouth of the river, and the actual record could have come from further upstream. Therefore, the only reliable closest record is the one from Rio do Peixe State Park, which was confirmed by the authors based on a photograph of a specimen from "Córrego do Prado", a tributary of the Rio do Peixe (Nelson Gallo, in litt.).

The absence of roadkill records of $C$. minimus is congruent with previous studies (Prada 2004, Coelho et al. 2008, Caires et al. 2019, Magioli et al. 2019), even though the recorded individuals frequently used areas adjacent to the studied highway. Vehicle collision rate seems to be low for C. minimus even when compared with other semi-aquatic mammals such as the capybara (Hydrochoerus hydrochaeris) and the Neotropical otter (Lontra longicaudis) (Coelho et al. 2008, Huijser et al. 2013, Magioli et al. 2019). A plausible explanation for the rarity of roadkills is that $C$. minimus seems to never leave watercourses during its daily movements (Leite et al. 2016).

Although C. minimus is currently listed as "Least Concern" by the IUCN Red List (Pérez-Hernandez et al. 2016), mainly due to its wide distribution, the species may be locally rare and vulnerable (e.g. Conselho Estadual de Política Ambiental 2010) and some of the populations seem to be decreasing (Pérez-Hernandez et al. 2016). 
Therefore, we suggest that streams crossing highways through culverts can mitigate highway impacts on $C$. minimus by promoting connectivity and reducing the mortality risk of the species.

Our results indicate that $C$. minimus can tolerate a moderate level of disturbance, as long as the water bodies and riparian forests are minimally preserved. Conversely, the relatively close protected areas may act as refuges for the species in the region, even though there are no direct river connections between the study area and the Rio do Peixe State Park, the nearest protected area. Finally, we reinforce the importance, in road ecology studies, of setting camera traps at strategic locations when sampling for taxa that have specific habitat requirements.

\section{Supplementary Material}

The following online material is available for this article:

Table S1 - Geographical coordinates of the nine camera-trap stations placed at underpasses of the SP-270 highway in São Paulo state, Brazil.

\section{Acknowledgements}

We are grateful to CART (Concessionária Auto Raposo Tavares S/A), the company responsible for the highway where our study was conducted, and that made our data collection possible. Three anonymous referees provided helpful comments and suggestions that substantially improved this manuscript.

\section{Author Contributions}

Paula Ribeiro Prist: Substantial contribution in the concept and design of the study; Contribution to data collection; Contribution to data analysis and interpretation; Contribution to manuscript preparation; Contribution to critical revision, adding intellectual content.

Guilherme S. T. Garbino: Substantial contribution in the concept and design of the study; Contribution to data analysis and interpretation; Contribution to manuscript preparation; Contribution to critical revision, adding intellectual content.

Fernanda Delborgo Abra: Substantial contribution in the concept and design of the study; Contribution to data collection; Contribution to data analysis and interpretation; Contribution to manuscript preparation; Contribution to critical revision, adding intellectual content.

Thais Pagotto: Contribution to data collection.

Osnir Ormon Giacon: Contribution to data collection.

\section{Conflicts of Interest}

The authors declare that they have no conflict of interest related to the publication of this manuscript.

\section{Ethics}

This study did not involve animal experimentation or collecting.

\section{Data Availability}

Every information necessary to replicate this study is present in the manuscript text.

\section{References}

ARDENTE, N., GETTINGER, D., FONSECA, R., BERGALLO, H.D.G. \& MARTINS-HATANO, F. 2013. Mammalia, Didelphimorphia, Didelphidae, Glironia venusta Thomas, 1912 and Chironectes minimus (Zimmermann, 1780): Distribution extension for eastern Amazonia. Check List 9(5):1104-1108.

ASTÚA, D. 2015. Family Didelphidae (Opossums). In Handbook of the Mammals of the World, Monotremes and marsupials, Vol. 5 (D. E. Wilson \& R. A. Mittermeier, eds) Lynx Edicions, Barcelona, p.70-186.

BRANDÃO, M.V., GARBINO, G.S.T., GODOY, L.P., DA SILVA, L.A. \& PASCOAL, W. 2015. New records of Chironectes minimus (Zimmermann, 1870) (Didelphimorphia, Didelphidae) from central Brazil, with comments on its distribution pattern. Mammalia 79(3):363-368.

BRESSIANI, V.B. \& GRAIPEL, M.E. 2008. Comparação de métodos para captura da cuíca-d’água, Chironectes minimus (Zimmerman, 1780) (Mammalia, Didelphidae) no sul do Brasil. Mastozoología Neotrop. 15(1):33-39.

BREVIGLIERI, C.P.B. \& PEDRO, W.A. 2010. Predação de morcegos (Phyllostomidae) pela cuíca d'água Chironectes minimus (Zimmermann, 1780) (Didelphimorphia, Didelphidae) e uma breve revisão de predação em Chiroptera. Chiropt. Neotrop. 16(2):732-739.

CAIRES, H.S., SOUZA, C.R., LOBATO, D.N.C., FERNANDES, M.N.S. \& DAMASCENO, J.S. 2019. Roadkilled mammals in the northern Amazon region and comparisons with roadways in other regions of Brazil. Iheringia, Ser. Zool. 109e2019036.

CARVALHO, C.T. De. 1965. Bionomia de pequenos mamíferos em Boracéia. Rev. Biol. Trop. 13(2):239-257.

COELHO, I.P., KINDEL, A. \& COELHO, A.V.P. 2008. Roadkills of vertebrate species on two highways through the Atlantic Forest Biosphere Reserve, southern Brazil. Eur. J. Wildl. Res. 54(4):689-699.

CONSELHO ESTADUAL DE POLÍTICA AMBIENTAL. 2010. Lista de Espécies Ameaçadas de Extinção da Fauna do Estado de Minas Gerais. Deliberação Normativa. $\mathrm{N}^{\circ} 147$.

FARIA, H.H. \& PIRES, A.S. 2006. Parque Estadual do Morro do Diabo: plano de manejo. Editora Viena, Santa Cruz do Rio Pardo, SP.

FARIA, H.H. \& PIRES, A.S. 2010. Parque Estadual do Rio do Peixe: plano de manejo. Secretaria do Meio Ambiente. São Paulo.

FERNANDEZ, F.A.S., GALLIEZ, M., LEITE, M. de S., QUEIROZ, T.L. \& PALMERIM, A.F. 2015. Natural history of the water opossum Chironectes minimus: a review. Oecologia Aust. 19(1):47-62.

GALLIEZ, M., LEITE, M.S., QUEIROZ, T.L. \& FERNANDEZ, F.A.S. 2009. Ecology of the water opossum Chironectes minimus in Atlantic Forest streams of southeastern Brazil. J. Mammal. 90(1):93-103.

GONZÁLEZ-GALLINA, A., HIDALGO-MIHART, M.G. \& CASTELAZOCALVA, V. 2018. Conservation implications for jaguars and other neotropical mammals using highway underpasses. PLoS One 13(11):1-20.

GREGORY, T., LUNDE, D., ZAMORA-MEZA, H.T. \& CARRASCO-RUEDA, F. 2015. Records of Coendou ichillus (Rodentia, Erethizontidae) from the lower Urubamba region of Peru. Zookeys 509: 109-121.

GRILO, C., BISSONETTE, J.A. \& SANTOS-REIS, M. 2008. Response of carnivores to existing highway culverts and underpasses: implications for road planning and mitigation. Biodivers. Conserv. 17(7):1685-1699.

HUIJSER, M.P., ABRA, F.D. \& DUFFIELD, J.W. 2013. Mammal road mortaliy and cost-benefit analyses of mitigation measures aimed at reducing collisions with capybara (Hydrochoerus hydrochaeris) in São Paulo state, Brazil. Oecologia Aust. 17(1):129-146.

INMET. 2019. Instituto Nacional de Meteorologia. Normais climatológicas do Brasil, período 1981-2010. http://www.inmet.gov.br/ (last access in 21/08/2020).

LEITE, M. de S., GALLIEZ, M., QUEIROZ, T.L. \& FERNANDEZ, F.A.S. 2016. Spatial ecology of the water opossum Chironectes minimus in Atlantic Forest streams. Mamm. Biol. 81(5):480-487.

LEITE, M.S., QUEIROZ, T.L., GALliEZ, M., MENDONÇA, P.P. \& FERNANDEZ, F.A.S. 2013. Activity patterns of the water opossum Chironectes minimus in Atlantic Forest rivers of south-eastern Brazil. J. Trop. Ecol. 29(3):261-264. 
MAGIOLI, M., BOVO, A.A.A., HUIJSER, M.P., ABRA, F.D., MIOTTO, R.A., ANDRADE, V.H.V.P., NASCIMENTO, A.M., MARTINS, M.Z.A. \& FERRAZ, K.M.P.M. de B. 2019. Short and narrow roads cause substantial impacts on wildlife. Oecologia Aust. 23(1):99-111.

MELO, G.L. \& SPONCHIADO, J. 2012. Distribuição geográfica dos marsupiais no Brasil. In Os marsupiais do Brasil: biologia, ecologia e conservação (N. C. Cáceres, ed.) Editora UFMS, Campo Grande, p.93-110.

MITTERMEIER, R.A., TURNER, W.R., LARSEN, F.W., BROOKS, T.M. \& GASCON, C. 2011. Global biodiversity conservation: the critical role of hotspots. In Biodiversity hotspots (F. E. Zachos \& J. C. Habel, eds) Springer, London, p.3-22.

NOGUEIRA, J.C., CASTRO, A.C.S., CÂMARA, E.V.C. \& CÂMARA, B.G.O. 2004. Morphology of the male genital system of Chironectes minimus and comparison to other didelphid marsupials. J. Mammal. 85(5):834-841.

O’BRIEN, T.G., KINNAIRD, M.F. \& WIBISONO, H.T. 2003. Crouching tigers, hidden prey: Sumatran tiger and prey populations in a tropical forest landscape. Anim. Conserv. 6:131-139.

OLIVEIRA-SANTOS, L.G.R., TORTATO, M.A. \& GRAIPEL, M.E. 2008. Activity pattern of Atlantic Forest small arboreal mammals as revealed by camera traps. J. Trop. Ecol. 24(5):563-567.

PALMEIRIM, A.F., LEITE, M.S., SANTOS-REIS, M. \& FERNANDEZ, F.A.S. 2014. Habitat selection for resting sites by the water opossum (Chironectes minimus) in the Brazilian Atlantic Forest. Stud. Neotrop. Fauna Environ. 49(3):231-238.

PELZELN, A. von. 1883. Brasilische Säugethiere: resultate von Johann Natterer's Reisen in den Jahren 1817 bis 1835. Verhandlungen der Zool. Gesellschaft Österreich 33(Suppl.1):1-140.

PÉREZ-HERNANDEZ, R., BRITO, D., TARIFA, T., CÁCERES, N., LEW, D. \& SOLARI, S. 2016. Chironectes minimus. IUCN Red List Threat. Species e.T4671A22173467.
PRADA, C. de S. 2004. Atropelamento de vertebrados silvestres em uma região fragmentada do nordeste do estado de São Paulo: quantificação do impacto e análise de fatores envolvidos. Tese de Doutorado. Universidade Federal de São Carlos.

REZENDE, G.C. 2014. Mico-leão-preto: a história de sucesso na sonservação de uma espécie ameaçada. Matrix, São Paulo.

RIBEIRO, M.C., METZGER, J.P., MARTENSEN, A.C., PONZONI, F.J. \& HIROTA, M.M. 2009. The Brazilian Atlantic Forest: How much is left, and how is the remaining forest distributed? Implications for conservation. Biol. Conserv. 142(6): 1141-1153.

STEIN, B. \& PATTON, J. 2008. Genus Chironectes Illiger, 1811. In Mammals of South America, Volume 1: marsupials, xenarthrans, shrews, and bats (A. L. Gardner, ed.) University of Chicago Press, Chicago, IL, p.14-17.

TOBLER, M.W., CARRILLO-PERCASTEGUI, S.E., LEITE PITMAN, R., MARES, R. \& POWELL, G. 2008. An evaluation of camera traps for inventorying large- and medium-sized terrestrial rainforest mammals. Anim. Conserv. 11(3):169-178.

UEZU, A. 2006. Composição e estrutura da comunidade de aves na paisagem fragmentada do Pontal do Paranapanema. Tese de Doutorado, Universidade de São Paulo, São Paulo.

VALLADARES PADUA, C. 2007. Plano de Manejo da Estação Ecológica MicoLeão-Preto. Instituto Chico Mendes de Conservação da Biodiversidade. Brasília, DF.

VOSS, R.S., LUNDE, D.P. \& SIMMONS, N.B. 2001. The mammals of Paracou, French Guiana: a neotropical lowland rainforest fauna. Part 2. Nonvolant species. Bull. Am. Museum Nat. Hist. 263:1-236.

Received: $04 / 06 / 2020$

Revised: $21 / 08 / 2020$

Accepted: $25 / 08 / 2020$

Published online: 21/09/2020 